\title{
XXXVIII. Experiments and observations on feathers, and the down of domestic fowls
}

\section{Parmentier}

To cite this article: M. Parmentier (1804) XXXVIII. Experiments and observations on feathers, and the down of domestic fowls, Philosophical Magazine Series 1, 20:79, 211-217, DOI:

$10.1080 / 14786440408676631$

To link to this article: http://dx.doi.org/10.1080/14786440408676631

Published online: 18 May 2009.

Submit your article to this journal $₫$

Џ Article views: 2

Q View related articles $\widetilde{ }$ 
be formed, through which a current will spirt while the supply is on, and as long afterwards as any water remains in the pipe. This hole may be stopped with a nail in general, and only left open in frosty weather; when the water, which will run to waste at each supply, will scarcely exceed a few pails full. In pipes that are already laid, should the lowest part of the course not be conveniently situated for the draining of the pipe, as in an area, or over a sink, such alteration must be made in shaping the course of the pipe, as will place its lowermost part in a convenient situation for draining. But in pipes that are to be new laid (if what I have elready said is understood) it will be obvious, that when a deflection between the main and cistern is necessary, the lowest angle or part thereof should be fixed in a convenient situation for draining the pipe, as over a sink; and to this, point the whole of the pipe must incline. I have taken some pains in examining the laying of pipes in manufactories, \&c.; and I have met with no instance wherein the necessary deflections of a pipe might not be reduced to one lowermost angle, to effect the exhaustion of the whole course.

Should the small current alluded to be found an objection, 2s continuing during the whole of the supply, the peg need only be removed for one or two minutes, within a few hours after the supply has ceased, when the waste water will be drawn off before a formation of ice can take place.

XXXVIII. Experiments and Observations on Feathers, and the Down of domestic Fowls. By M. Parmentier*.

$\mathrm{B}$ $B_{\text {IrDs are caught and reared not only for the sake of their }}$ flesh, their fat, and their eggs, but also on account of their feathers: the feathers, given them by nature for their clothing, and to form their principal means of flight, are applied to different purposes more or less useful to society.

Some, remarkable for their softness and elasticity, for the beauty of the filaments of which their barbs are composed, serve to overshadow the helmets of warriors, to ornament the bead-dress of ladies, to form those tresses and those elegant plumes by which the richest articles are surmounted.

Others, sought for on account of the length and solidity of their barrels, and the facility with which they can be cut at

- Fram Anrales de Cómie, No I ju.

$\mathrm{O} \&$ 
pleasure for writing, become the interpreters of our thoughts. Among the Europeans, they form an advantagcous substitute for the reeds employed by the Araps, and for the style with wich the antients engraved upon tablets.

There are feathers also proper for filling those cushions, on which, when fatigued with the labours of 'the day, we repose duting the night. It is from ainong the latter that Luxury herself has selected some of peculiar fineness, lighthest, and elasticity, to form of them a bed on which she enjeys gentre sleep.

\section{Plumes and other. Ornaments of Luxury.}

The most beautiful and most esteemed of all the plumes are those made of the feathers of the ostrich, that singulat biped, which bas its feet and parts of generation like those of quadrupeds, the bead of birds, and the faculty of laying the stomact and intestines of ruminating animals, and yet the gizzard of fowls; which has its body covered partly with hair and partly with feathers; in a word, which has wings which are not the instruments of flying, but only a kind. of balances, with which it supports itself, and easily preserves an equilibrium in the exceedingly rapid courses which it performs in the deserts of Africa.

The plumage of the male is black, with some gray and white feathers; that of the female is brown, and of an ash gray; the large feathers of the wings and tail are white in the male and black in the female.

What in particular distinguishes these large feathers, and renders them proper for making plumes, is, that they are soft, open, and flexible; that their barbs, composed of detached filaments, without consistence and adhesion, are long and full; and, lastly, that the white plumes of the male are succeptible of assuming the finest tints.

The rarity and high price of these ostrich feathers, which are brought to us from the Levant, might, no doubt, have suggested the idea of naturalising these bitds in Europe; had it been believed that they were capable of residing in any place but the burning sands of Arabia. But there is another kind of ostrich, that of Magetlan, which, imhabiting the cold districts of South America, might thrive in our climates: it would be necessary to introduce it, and to try to multiply the breed, in order to take advantage of its eggs, its flesh, and its feathers.

In the mean time, there is another speculation which would succeed more specdily, and with more certainty; it is wo multiply white turkess, and to employ for plumes the 
feathers found on the lateral part of the thighs of these animals. This substitute for ostrich feathers would become useful to commerce.

Besides the large ostrich feathers which are seen waving with so much grace over the head-dress of ladies, there are some taken from other birds which serve also for ornamenting these heads: of this kind are the feathers of the bird of paradise, and particularly the long and beautiful black feathers which proceed from the top of the head of the heron, forming an aigrette, which is balanced on their neck.

Luxury adorns itself also with the feathers of the peacock : the colours of gold and of precious stones which nature has bestowed in profusion on the tail of this beautiful bird, are its exclusive property; those of the golden birds, the humming bird, and others of the large fanily of the woodpeckers exhibit the freshness and velvety appearance of flowers, the polish of the most brilliant metals, the splcndour of the most precious stones, and the variegated and dazzling reflection of the rays of the sun. It has employed, in trimming rubes, the beautiful yellow and brilliant feathers of the neck of the toucan. It has not even disdained to use, for the like purpose, the azured feathers of the jay, and with which that in the fable was not contented.

So active a war was carried on some time ago against these birds, in order io obtain their feathers, that the farmers flattered themselves with the hope of being soon freed from them. Unfortunately the rage for the feathers of the jay is over, and that bird continues, as before, to ravage the fields.

Not satisfied with objects of ornament, for which luxury employed those feathers, embellished with the must brilliant colours, the idea has beell conceived of rendering them useful.

It is with skins furnished with feathers of the same birds, to which are added those of the swan, duck, diver, pintado, pheasant, \&c. that muffs and palatines are made.

The skins destined for this purpose, says M. Vieillot in the Nouveau Dictionnaire d'Histoire Naturelle, ought not to be those of birds which have died of discase, or which have been killed in moulting-time; in this case the feathers would drop off, or would not be in a state of perfection. None, therefore, must be emploved but those of birds killed in their state of perfection, and stripped off soon after their death, especially when the weather is hot; otherwise the same effects would result from corruption as from disease.

When the skin has been freed from all its impurities, it 
is spread over a small table, the plumage downwards, and the feathers previously well arranged over each other. To stretch it better, it is fixed with pins, or with a thread.

The grease and flesh which may adhere to it, are then removed, and the rents in it, if any, are sewed up; the skin is then covered with glue, prepared from a handful of farina, a pinch of common salt, and as much good white wine as is necessary to mix it up and bring it to the proper consistence.

The skin being thus covered is exposed to dry to the north wind, after which it is cleaned by scraping it ; which may be easily done, as the glue detaches itself in scales. After this operation, if it still retain any humidity, it must be again covered with glue, and dried as before.

When well dried, it is fixed with thread upon paper, or on a ribbon, to preserve it, and inclosed in a box, the bottom of which is covered with absynthium or rose-wood. If an agreeable odour be required in the skin, it will be necessary, before it is taken from the table, and after it has been scraped, to give it, with a sponge, a stratum or two of some odoriferous composition.

When the skins are those of large birds, vinegar, in which salt or alum has been dissolved, is used instead of wine; several strata of this mixture are daubed over them; the quantity depends on the thickness of the skin.

\section{Writing Quills.}

Pens, for such is the name given to the feathers of the wings and tails of birds, to distinguish them from the feathers, properly sa called, by which their bodies are covered, are the longest and strongest of all the feathers; those of swans, geese, and crows, are employed in preference to all others for economical purposes, and according to the quality of their barrels,

Thus, the quills of the swan are most esteemed for writing and for forming brushes; those of the goose, which are more plentiful, and almost as good as those of the swan, are more generally used for writing; and those of the crow are more particularly employed for the keys of harpsichords, and by draftsmen in thiose kinds of drawings which are executed with the pen.

\section{Method of Dutchifying Quills.}

The bird which supplies the greatest quantity of writingpens is the goose. One furnishes quills of ten different qualities; but there always remains on their surface a greasy matter, from which they must be freed to render them pure, 
transparent, shining, and, in a word, proper for acquiring the necessary qualities. This preparation is generally given to them by the Dutch. Hence the expression of dutchifying quills to denote the operation to which they are subjected. I took advantage of the circumstances of the war, when several apothecaries, acquainted with the arts and sciences, were employed in Batavia, to request them to procure some information in regard to a process which is still very little known. The following is the substance of what was communicated to me:

The process consists in immersing the quill, when plucked from the wing of the bird, into water almost boiling; to leave it there till it becomes sufficiently soft; to compress it, turning it on its axis with the back of the blade of a knife. This kind of friction, as well as the immersions in water, being continued till the barrel of the quill be transparent, and the membrane as well as the greasy kind of covering be entirely removed, it is immersed a last time to render it perfectly cylindrical, which is performed with the index finger and the thumb: it is then dried in a gentle temperature.

Feathers and Down for Cushions.

Pillows, mattresses, and cushions, may be filled with the small feathers of domestic fowls and pigeons. There are some cantons in which they are employed for this purpose; but for the most part the down of the palmipedes is chosen. Those of birds of prey might be employed also, were they sufficiently numerous to promise abundance.

There are two kinds of down. One, which is neglected, consists of light soft barbs, open, bristly, and without connection, which cover a great many young birds soon after birth, aud which drop off in proportion as they are developed. The other, more adherent, which are carefully collected, consist of those short feathers, with slender barrels, and long, equal, disunited barbs, with which nature has composed the warm clothing of birds which take a high flight, and those which are aquatic, in order to secure them from the cold they would otherwise experience, the one in the upper regions of the atmosphere, and the other from the contact of the water. This down in the latter is covered with a close oily plumage, which preserves it entirely from humidity, and by these incans permits these birds to preserve their natural heat.

The down of birds of prey, known under the name of eider down, being, as already said, exceedingly rare, collectors endeavour to obtain only that of palmipedes; a very 
numerous class of birds, and of which three species onit" have leen-subjected to the condition of domesticity; viz. the swan, goose, and duck.

But before I apeak of the collecting of these three kinds of down, which are readily obtained, I shall say a few words in regard to a kind of down which is far superior to them on account of its softness, lightness, and elasticity; it is the eider doivn, furnished by a duck called the eider duck (Anas mollissima Linn.), which inbabits Iceland. The following is the description given of it by Sonnini, the worthy friend of Buffon, and one of the principal co-operators in the Nouveau Dictionnaire d'Histoire Naturelle:

c The eider duck pulls from its breast and belly the down with which they are covered, in order to line its nest to warm its eggs and its young. It is sought for with great care in all countries where these birds are common. It is the softest, the lightest, warmest, and most elastic of all the kinds of down. Norway and Iceland furnish this valuable substance, which is sold there at the rate of a pistole per pound when pure and well picked.

4 The nests of the eider duck are in the north of Europe, to the inhabitants of the coasts, a sort of property which though free is constant and certain. Each individual enjoys in peace the nests situated on his land, and does every thing in his power to draw thither these ducks. A heavy fine is imposed on those who kill any of these birds. One man, if his bahitation be placed on one of the rocks at a distance from the land, can collect in a year from fifty to a hundred pounds of down. The Danes purchase all they collect. But it is a general rule that the down taken from a dead eider duck is inferior in quality to that which it plucks from its own body.". I have arready made this observation, and shall here add that it is general for all birds.

There is, indeed, a very great difference hetween feathers plicked from a living animal and those taken from one which has died in consequence of disease. The latter have very little elasticity; their barbs become matted when exposed to the least humidity. They are attended also with another inconvenience, which is, that though baked in an oven they areattacked more readily by insects, and in a little time reduced to dust.

But this difference is observed not merely in the feathers of domestic animals; wool and hair are equally subject to it. Wool shorn from an animal which has died of disease is not nearly so valuable as that cut from a sheep in good health. The state of the disease even lessens the qua- 
Dutch Processes in regard to the Arts and Sciences. 217

lity in a considerable degree. All cloth made of hair cut from an animal which has died of disease is destitute of strength. Merchants, therefore, are very careful to say that their hair is the product of a living animal ; and they are no donbt taught by daily practice to distinguish it.

Even ivory which is collected by chance in countries inhabited by elephants is inferior to that obtained from elephants which are hunted : the latter being whiter, less brittle, finer, and susceptible of a better polish, and in every respect superior.

XXXIX. Olservations on some Dutch Processes in regard to the Arts and Sciences. By M. Parmentien *.

As we have had a camp at Utrecht, and as government attached to it M. Payssé in the quality of apothecary in chief, I flattered myself, from the knowledge I have of the zeal and talents of that chemist, that by requesting him to take advantage of his stay in Batavia to examine the cabinets of natural history, to visit the workshops, laboratories, and manufactories, and particularly to frequent the company of the professors with whom I maintain a correspondence, it would be possible to obtain some useful information in regard to certain processes of which the Dutch seem to have been in exclusive possession since time immemorial. My hopes have not been deceived; and I shall here give an extract of the different letters $I$ received from M. Payssé : it is he himself who gives an account of what he collected in his excursions.

"Our camp at Utrecht is very beautiful, and as advantageously situated as local circumstances will permit. Water is good and abundant. The evenings are rather cool, in consequence of the ground having very little shelter, and of the condensation of the water with which the air is always saturated. There are not so many sick as we at first imagined; and we hope that in the autumn, which is the season of disease to military people in this country, we shall have very few, or a much smaller number of sick than we have in our hospitals, in consequence of the means of salubrity which have been recommended to us, and the great care employed both in the camp and in the hospitals.

"I have had the pleasure of spending a day at Leyden

* From Annales de Cbimie, Na. Is 1 . 